\title{
Colgajo libre radial de doble paleta cutánea para reconstrucción de lengua y suelo de boca
}

\section{Double pad radial free flap to reconstruct touque and floor of the mouth}

\author{
M. Acosta Feria 1 , P. Infante Cossío', A. García-Perla García', E. Torres Carranza', R. Belmonte Caro', \\ J.L. Gutiérrez Pérez ${ }^{3}$
}

Resumen: Introducción. La cirugía reconstructiva tras la exéresis de tumores malignos que afectan a la lengua y al suelo de boca, continúa siendo uno de los grandes retos de la cirugía oral y maxilofacial. La mayor recuperación del habla y de la deglución, van a ser los objetivos finales de toda la reconstrucción de la cavidad oral. Presentamos un nuevo diseño del colgajo libre radial para la cirugía reconstructiva del carcinoma lengua y suelo de boca. Material y método. Nuestra serie consta de tres pacientes diagnosticados de carcinoma epidermoide de lengua y suelo de boca. Tras la cirugía oncológica ablativa, se reconstruyó el defecto oral con un colgajo libre radial de doble paleta cutánea con zona intermedia desepidermizada microvascularizado. Resultados. La movilidad de la lengua de nuestros pacientes fue suficiente y adecuada, consiguiéndose una buena calidad de vida. No hubo pérdida de la comida u otros fluidos a través del tracto respiratorio. Conclusiones. Con el colgajo radial de doble paleta cutánea microvascularizado, se consigue una buena recuperación funcional tanto en el habla como en la deglución en los pacientes, por lo que creemos que debería estandarizarse su uso en la cirugía reconstructiva oral tras la exéresis de tumores malignos de lengua y suelo de boca.

Palabras clave: Colgajo libre radial; Carcinoma de lengua; Reconstrucción de la cavidad oral.

Recibido: 22.09 .2005

Aceptado: 04.07.2006
Abstract: Introduction: The firearm injuries are not very common in our country, and the experience in its management is limited. In this review we show the experience of our Service in this wounds and review the literature to systematize the initial management of the firearm injuries in maxillofacial region. Material and Methods: We present six patients treated in our Service in 2002. We study the demographics characteristic, aetiology, lesions patterns and treatment. Results: Five male and a female were treated of firearm lesions during this period, with a mean age of 38 years (range 13-74). Most frequent aetiology was the aggression. Only one patient required emergency airway control with tracheotomy. No complications were noted after primary surgical treatment and only one patient needed secondary surgical intervention. Discussion: There are controversy in definitive surgical treatment in patients with high-energy lesions in maxillofacial region, because the literature describe two forms of management. The first way is the primary reconstruction with microvascular techniques, or secondary reconstruction after desbridement, stabilization of existing bone and primary closure of soft tissue. We think that the choice of treatment must be individualized, and we choose the secondary reconstruction as early as possible after primary stabilization of wounds.

Key words: Firearm; Maxillofacial injuries; Reconstruction.

1 Médico Residente.

2 Médico Adjunto.

3 Jefe de Servicio.

Servicio de Cirugía Oral y Maxilofacial.

Hospitales Universitarios Virgen Del Rocío. Sevilla, España.

Correspondencia:

Dr. M. Acosta Feria

H.U. Virgen del Rocío

Avda. Manuel Suirot s/n

41013 Sevilla, España

e-mail:Te_ba@hotmail.com 


\section{Introducción}

La cirugía reconstructiva tras la resección de tumores de cabeza y cuello ha experimentado un gran avance y perfeccionamiento en los últimos años, cambiándose los objetivos de dicha cirugía, que van desde el cierre directo en un comienzo, hasta las formas más complejas de restauración en la actualidad, y que permiten restituir la estructura anatómica y funciones de las partes resecadas. ${ }^{1}$ El principal objetivo de toda reconstrucción es conseguir la máxima recuperación funcional del paciente, siendo la reconstrucción de la lengua el factor más importante en dicha recuperación. Sin embargo, la complejidad en la disposición de las fibras musculares linguales y el extraordinario rango de movimientos de las mismas aún no se ha podido alcanzar con las técnicas reconstructivas actuales. Lo que sí se sabe es que, tras la glosectomía parcial, es primordial mantener la movilidad de la lengua residual mientras se restaura el revestimiento mucoso oral. Los colgajos libres inervados se han propuesto como la otra forma de garantizar un alto grado de recuperación de la deglución, habla y protección de la vía aérea en la reconstrucción de la lengua.

Dentro de los colgajos libres utilizados en la reconstrucción lingual, el colgajo libre radial microvascularizado, popularizado por Soutar, ${ }^{2}$ se ha convertido en el de elección, no sólo para la reconstrucción lingual, sino, en general, para los tejidos blandos de la cavidad oral y faringe. ${ }^{3,-6}$. El colgajo radial proporciona un tejido delgado, redundante, plegable y flexible, características que son críticas a la hora de conservar la movilidad lingual. 3, 6,7

En 1994 Urken diseñó el colgajo radial bilobulado fasciocutáneo, que permite separar en la reconstrucción oral la lengua móvil del suelo de la boca y encía, con lo cual se maximiza la movilidad postoperatoria de la neolengua. ${ }^{8}$

Tras la bibliografía consultada, presentamos un nuevo diseño del colgajo radial microvascularizado, realizando una modificación a los ya descritos, al independizar totalmente mediante una zona desepidermizada dos paletas cutáneas para recrear la forma anatómica nativa de la lengua y el suelo de boca. Así, por tanto, se individualiza la reconstrucción de la lengua de la del suelo de boca y encía. Nuestro colgajo fue utilizado para la reconstrucción de la cavidad oral en tres pacientes a los que se les diagnosticó un carcinoma epidermoide de lengua y suelo de boca, realizándose cirugía oncológica ablativa en todos los casos.

\section{Material y método}

Presentamos tres pacientes diagnosticados de carcinoma epidermoide de lengua y suelo de boca de $4 \mathrm{~cm}$ de diámetro con extensión a estructuras vecinas (T3). Se realizó glosectomía parcial y exéresis del suelo de boca reconstruyendo el defecto quirúrgico con un colgajo libre radial con dos paletas cutáneas separadas por una zona intermedia desepidermizada. No se observó en ninguno de los casos fallos en el colgajo ni otras complicaciones. Los pacientes fueron operados entre 2000 y 2001 . El rango de seguimiento fue de 12 a 18 meses.

\section{Introduction}

Reconstructive surgery following the resection of tumors of the head and neck has seen great advances over recent years, and it has been perfected. The surgical objectives have changed, as initially these just entailed direct closure, while now these involve the more complex forms of current restorations, which permit the restoration of the anatomic structure and functions of the resected areas. ${ }^{1}$ The principal objective of all reconstruction is to achieve maximum functional recovery for the patient, with the reconstruction of the tongue being the most important factor in this recovery. However, current reconstructive techniques have still to achieve the complex arrangement of the tongue's muscle fibers and its extraordinary range of movements. What is known is that after a partial glossectomy, maintaining the mobility of the residual tongue is of primordial importance while restoring the mucosal surface of the mouth. The innervated free flaps have been proposed as the other form of guaranteeing a high degree of recovery with regard to swallowing, speech and protection of the airways in the reconstruction of the tongue.

Of the free flaps used in lingual reconstruction, the radial microvascularized forearm free flap popularized by Soutar ${ }^{2}$, has become the flap of choice, not only for reconstruction of the tongue, but in general for soft tissues of the oral cavity and pharynx. ${ }^{3-6}$ The radial forearm flap provides thin tissue that is superfluous, malleable and flexible, characteristics that are critical when conserving the mobility of the tongue.3,6,7

In 1994 Urken designed a bilobed fasciocutaneous radial forearm flap that enabled separating the mobile tongue from the floor of the mouth and gums during the reconstruction. As a result the postoperative mobility of the new tongue was maximized. 8

After consulting the literature, we present a new design for a microvascularized radial forearm flap, following a modification of those already described, by making two totally independent skin paddles by means of a de-epithelialized zone in order to recreate the natural anatomic shape of the tongue and floor of the mouth. Thus, the reconstruction of the tongue and the floor of the mouth and gums are individualized. Our flap was used in the reconstruction of the oral cavity of three patients who were diagnosed with squamous cell carcinoma of the tongue and floor of the mouth, and who all underwent oncological ablative surgery.

\section{Material and method}

We present three patients who were diagnosed with squamous cell carcinoma of the tongue and floor of the mouth. The areas measured more than $4 \mathrm{~cm}$ in diameter and there was extension to neighboring structures (T3). A partial glossectomy and exeresis of the floor of the mouth was carried out and the surgical defect was reconstructed with a radial forearm free flap with two skin paddles that were separated by an intermedi- 
La intervención quirúrgica fue realizada por dos equipos en cada paciente; el primer equipo, llevó a cabo la exéresis del tumor y la disección cervical, mientras que el segundo extrajo el colgajo radial para la reconstrucción posterior. Se diseñaron dos paletas cutáneas con su eje mayor perpendicular a los vasos del antebrazo; la paleta distal se usó para la reconstrucción de la lengua y la proximal para el suelo de boca. La proporción de las dos paletas varió en función del defecto a reconstruir. Una zona intermedia desepidermizada entre ambas paletas de $1 \mathrm{~cm}$ de anchura, se diseñó a modo de puente, permitiendo una fijación anatómica mejor de ambas paletas cutáneas. El colgajo se insertó en la zona receptora. La zona distal de la paleta cutánea distal se suturó a la lengua, mientras que la zona proximal de la paleta cutánea proximal se suturó a la encía, permitiendo la zona desepidermizada la movilidad de ambas estructuras (Fig. 1). La anastómosis microvascular se llevó a cabo con ramas de la arteria carótida externa y del tronco tiro-linguofacial. El nervio cutáneo antebraquial lateral, se suturó al nervio lingual utilizando nylon 9-0.

\section{Paciente 1}

Paciente de 56 años con carcinoma epidermoide de lengua y suelo de boca, al que se le resecaron $2 / 3$ de la lengua móvil y el suelo de boca a través del abordaje pull-through. Se realizó una disección cervical supra-omo-hioidea bilateral. Se extrajo del brazo no dominante un colgajo libre radial con dos paletas cutáneas y una zona intermedia desepidermizada. El defecto lingual se reconstruyó con la paleta distal mientras que el suelo de boca se hizo con la proximal, separadas por una zona desepidermizada de $1 \mathrm{~cm}$. El paciente recibió radioterapia postoperatoria. El resultado al año de finalizar el tratamiento, se muestra en la figura 2. La recuperación funcional y de la sensibilidad de la neolengua fue buena. La alimentación por vía oral fue restaurada previo al alta del paciente. La movilidad de la lengua fue suficiente y adecuada para permitir el habla del paciente. El paciente recuperó la sensibilidad de la lengua después de tres meses de la intervención, mostrándose satisfecho con el resultado obtenido.

\section{Paciente 2}

Paciente varón de 51 años diagnosticado de carcinoma de células escamosas y adenopatías metastásicas cervicales, sufrió resección de 2/3 de la lengua y el suelo de boca. Se realizó una disección cervical supra-omo-hioidea bilateral. Se reconstruyó el defecto quirúrgico con un colgajo libre radial con dos paletas cutáneas ate de-epithelialized area. In none of the cases were the flaps seen to fail, nor were there any other complications. The patients were operated on between 2000 and 2001. The follow-up period ranged from 12 to 18 months. Two teams carried out the surgical intervention of each patient; the first team carried out the exeresis of the tumor and neck dissection, while the second removed the radial forearm flap for later reconstruction. Two skin paddles were designed with a longer axis that was perpendicular to the vessels in the forearm; the distal paddle was used for the reconstruction of the tongue, and the proximal paddle for the floor of the mouth. The proportion of the two paddles varied according to the defect to be reconstructed. An intermediate de-epithelialized area between both paddles with a width of $1 \mathrm{~cm}$ was designed as a sort of bridge, which permitted the improved anatomic fixation of both skin paddles. The flap was inserted in the receptor area. The distal area of the distal skin paddle was sutured to the tongue, while the proximal area of the proximal skin paddle was sutured to the gums, allowing the de-epithelialized area movement of both structures (Fig. 1). Microvascular anastomosis was carried out with branches of the external carotid artery and the thyro-linguo-facial trunk. The lateral antebrachial cutaneous nerve was sutured to the lingual nerve using 9-0 nylon.

\section{Patient 1}

Fifty-six year old patient with squamous cell carcinoma of the tongue and floor of the mouth. Two-thirds of the mobile tongue and of the floor of the mouth was removed by means of a pull-through procedure. Bilateral cervical supra-omohyoid dissection was carried out. A radial forearm free flap with two skin paddles and an intermediate de-epithelialized area was extracted from the non-dominant arm. The lingual defect was reconstructed with the distal paddle while the floor of the mouth was reconstructed with the proximal paddle, separated by a de-epithelialized area of $1 \mathrm{~cm}$. The patient received postoperative radiotherapy. The result a year after completing the treatment is shown in figure 2. The functional recovery and the sensitivity of the new tongue were good. Oral food intake was re-established prior to the patient's release. The mobility of the tongue was adequate and enough to enable speech. Sensation in the tongue was recovered three months after surgery, and the patient was satisfied with the results. 
y una zona intermedia desepidermizada (Fig. 3). El paciente recibió radioterapia postoperatoria. Se obtuvo a los 18 meses después de la intervención una buena recuperación funcional del habla y la deglución. La sensibilidad de la lengua reconstruida mejoró gradualmente tras la intervención. Tras cuatro meses, el paciente fue capaz de localizar estímulos dolorosos en diferentes puntos de la lengua.

\section{Paciente 3}

Paciente varón de 53 años que desarrollo después de recibir radioterapia una recurrencia de carcinoma epidermoide a nivel de 2/3 anteriores de la lengua. La porción móvil de la lengua se extirpó. Se realizo una disección radical derecha y supra-omo-hioidea izquierda. Se extrajo un colgajo libre radial con dos paletas cutáneas y una zona intermedia desepidermizada del brazo no dominante. La paleta cutánea proximal (de $6 \mathrm{~cm}$ de largo) fue usada para reconstruir la lengua, mientras que la distal se usó para restaurar el suelo de boca (Fig. 4). A los doce meses postoperatoriamente, la zona reconstruida presentaba una buena funcionalidad y buen aspecto estético. El paciente no necesito sonda de gastrostomía para su alimentación. La articulación de la palabra fue suficiente para permitirle realizar sus actividades normales. La recuperación de la sensibilidad en la lengua reconstruida se percibió tras dos meses desde la intervención. Poco a poco fue recuperando la percepción del dolor, temperatura y presión.

\section{Resultados}

En las revisiones que se llevaron a cabo tras el alta hospitalaria, se valoró el grado de recuperación funcional en el habla y en la deglución de los pacientes, así como la recuperación sensitiva de la zona receptora. Se observó una buena recuperación tanto en el habla como en la deglución en nuestros pacientes, objetivo final a lograr en toda reconstrucción tras la exéresis de carcinomas epidermoides de lengua y suelo de boca. Además, se consiguió una movilidad lingual

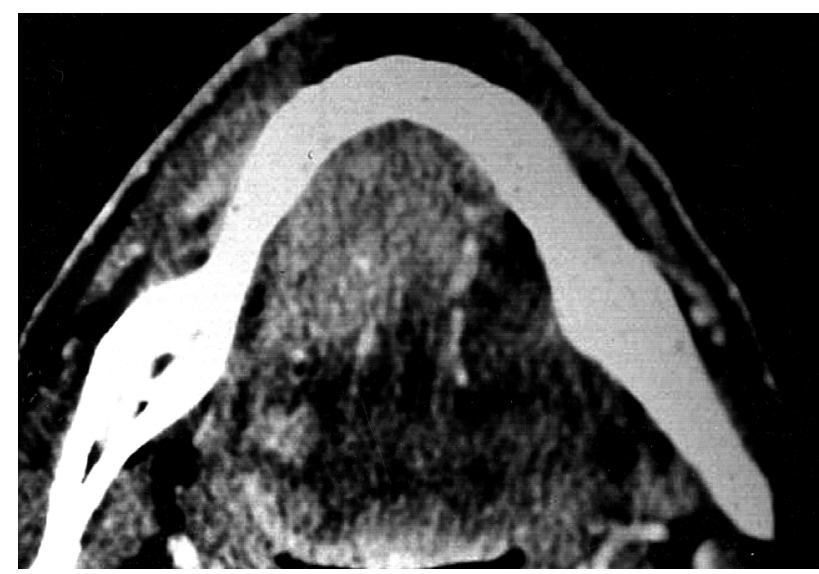

Figura 2A. Caso1, imagen de la TC mostrando la extensión del tumor.

Figure 2A. Case 1, CT image showing tumor extension.

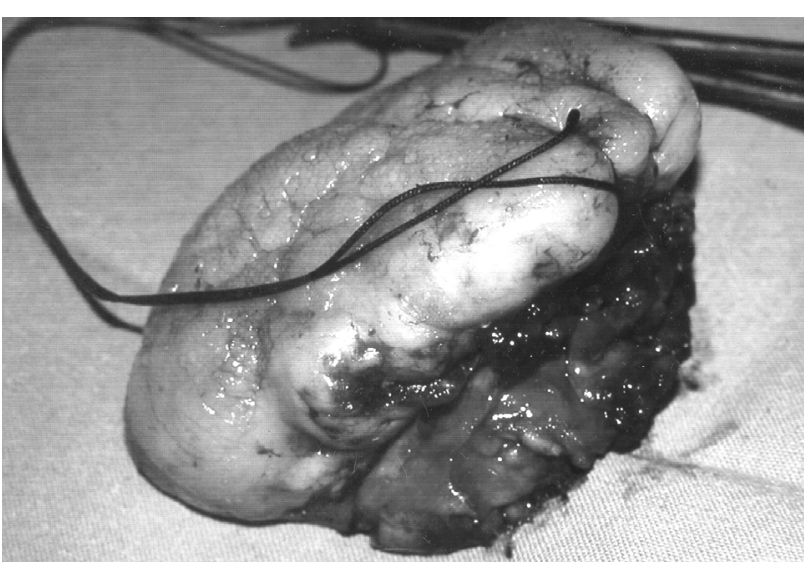

Figura 2B. Caso 1, imagen de la glosectomía subtotal. Figure $2 \mathbf{B}$. Case 1, image of subtotal glossectomy.

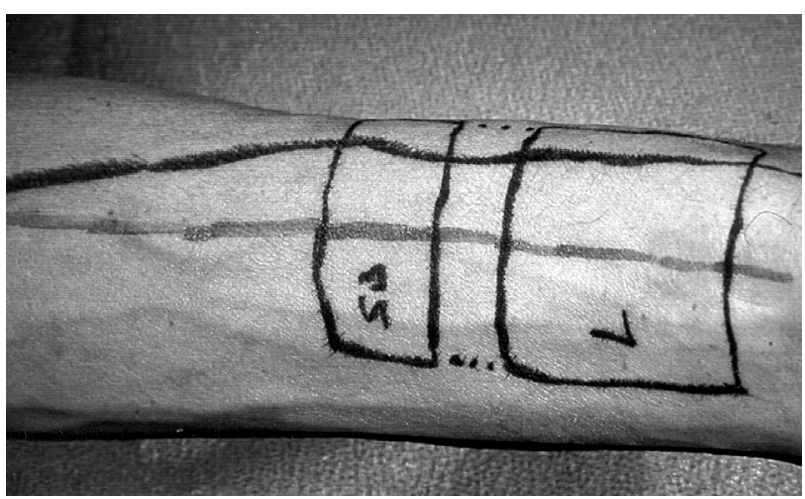

Figura 2C. Caso 1, diseño del colgajo radial con dos paletas cutáneas, paleta $L$ para la reconstrucción de la lengua, y paleta SB para la reconstrucción del suelo de la boca, mostrando también la arteria radial y la vena cefálica.

Figure 2C. Case 1, radial forearm flap design with two skin paddles, paddle $L$ for the reconstruction of the tongue, and paddle SB for the reconstruction of the floor of the mouth. The radial artery and the cephalic vein are also shown.

\section{Patient 2}

Male patient, 51 years old, diagnosed with squamous cell carcinoma and cervical metastatic lymph nodes. He underwent a resection of two thirds of the tongue and floor of the mouth. A bilateral cervical supra-omohyoid dissection was carried out. The surgical defect was reconstructed with a radial forearm flap with two skin paddles and an intermediate deepithelialized area (Fig. 3). The patient received postoperative radiotherapy. Eighteen months after the surgery he had good functional recovery of speech and swallowing. Sensation in the reconstructed tongue returned gradually after the surgery. After four months the patient was able to locate pain stimuli at different points of the tongue.

\section{Patient 3}

Male patient, 53 years old, experienced recurrence of squamous cell carcinoma in the anterior two-thirds of the tongue after radiotherapy. The mobile portion of the tongue was removed. Radical dissection was carried out of right side and the left supra-omohyoid side. A radial forearm free flap was harvested with two skin paddles together with an intermediate de-epithelialized area of the non-dominant arm. The proximal skin paddle $(6 \mathrm{~cm}$ long) was used for reconstructing the tongue, while the distal area was used for restoring the floor of the mouth (Fig. 4). Twelve months after surgery, the reconstruction showed good functional and aesthetic result. The patient did not need a gastrostomy feeding 
suficiente y aceptable, lográndose una buena calidad de vida en los pacientes. No se observó aspiración al tracto respiratorio de contenido alimenticio o de secreciones, ni se precisó la realización de gastrostomías de alimentación en ningún caso.

\section{Discusión}

El carcinoma de la cavidad oral se trata con cirugía, radioterapia o la combinación de ambos, dependiendo del tamaño tumoral, de la localización y de otros factores. La reconstrucción de la lengua es el factor fundamental para la recuperación funcional después de la cirugía ablativa oncológica en tumores malignos de cavidad oral. En la cavidad oral es particularmente importante que el método de reconstrucción mantenga las funciones del habla, masticación y deglución. La técnica reconstructiva ideal debe proporcionar: tejido blando viable con superficie epitelial semejante a la mucosa. Por último el colgajo también debe recubrir superficie ósea y resistir los traumas masticatorios. ${ }^{9}$

Hay múltiples factores que la cirugía reconstructiva no puede controlar cuando intenta la rehabilitación del paciente tras la glosectomía: la cantidad de lengua residual, la integridad de nervios motores y sensitivos, el grado de fibrosis de la musculatura de la lengua residual tras la cirugía y radioterapia, y otros factores dependientes del paciente (tales como la edad, condición médica y motivación). ${ }^{5}$ La funcionalidad de la lengua viene determinada por varios hechos: la actividad compleja de los diferentes músculos encargados de variar su forma y posición, la lubricación de la mucosa de revestimiento lingual, y la inervación sensorial feedback que proporcionan el dolor, la temperatura, el tacto, la propiocepción y el gusto. Para mejorar la movilidad de la lengua reconstruida, debemos tener en cuenta tres aspectos quirúrgicos: la introducción de un tejido delgado y plegable, el uso de tejido redundante y la separación a la hora de la reconstrucción de la lengua móvil del suelo de la boca y encía. ${ }^{8}$ La forma tradicional de reconstrucción tras la glosectomía ha sido la reconstrucción con colgajos miocutáneos libres o pediculados, siendo en la actualidad el colgajo libre radial el ideal para recuperar la máxima movilidad lingual, aunque para la reconstrucción de mayores defectos de partes blandas en la cavidad oral,se pueden usar otros colgajos, tales como el colgajo libre de recto. ${ }^{6}$

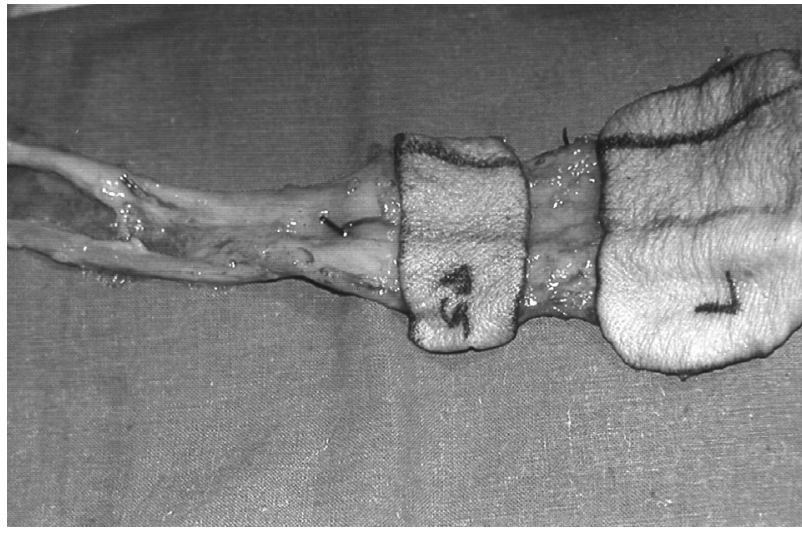

Figura 2D. Caso 1, imagen del colgajo libre radial. Podemos observar la zona desepidermizada entre las dos paletas cutáneas y el pedículo vasculonervioso del colgajo.

helialized Case 1, image of the radial forearm free flap. The de-epitflap's pedicle with the vascular and nerve supply.

Figura 2E. Caso 1, aspecto de la cavidad oral tras la reconstrucción de la lengua y el suelo de boca.

Figure $2 E$. Case 1, appearance of the oral cavity following reconstruction of the tongue and floor of the mouth. tube. His articulation was enough to enable him to carry out his normal activities. Sensation in the reconstructed tongue was recovered two months after the operation. Slowly his perception of pain, temperature and pressure returned.

\section{Results}

During the follow-ups carried out after their discharge, the extent of speech recovery as well as swallowing function was evaluated in all patients, in addition to sensory recovery in the receptor area. Good recovery was observed in speech as well as in swallowing in our patients, which is the final objective in all reconstruction after exeresis of squamous cell carcinomas of the tongue and floor of the mouth. In addition, lingual mobility that was sufficient and acceptable was achieved, and a good quality of life was achieved for the patients. Aspiration into the respiratory tract of food or secretions was not observed, and gastrostomy feeding was not required for any of the patients.

\section{Discussion}

Carcinoma of the oral cavity is treated with surgery, radiotherapy or a combination of both depending on the size of the tumor, the location and on other factors. The reconstruction of tongue is the basic factor for the restoration of function after ablative oncological surgery for malignant tumors of the oral cavity. It is particularly important in the oral cavity that the method of reconstruction maintains speech, mastication and swallowing functions. The ideal reconstruction technique should provide: viable soft tissue with an epithelial surface that is similar to mucosa. Lastly the flap should also cover the bone surface area and be resistant to masticatory trauma. ${ }^{9}$

There are multiple factors that reconstructive surgery is not able to control when the rehabilitation of a patient after a glossectomy is attempted: the quantity of the residual tongue, the integrity of motor and sensory nerves, the degree of fibrosis of the residual tongue musculature after surgery 
En 1994 Urken y cols., diseñaron el colgajo radial bilobulado, que permite separar, en la reconstrucción, la lengua móvil del suelo de boca y encía, con lo cual se maximiza la movilidad postoperatoria de la neolengua. ${ }^{8}$ Con nuestro nuevo diseño de doble paleta cutánea, aumentamos la movilidad de la lengua reconstruida, con lo que se mejora las funciones del habla, deglución y protección de vía aérea del paciente, al individualizar totalmente la reconstrucción de la lengua del suelo de la boca y encía, gracias a la zona que hemos desepidermizado.

El colgajo radial libre ha sido usado para la reconstrucción de defectos en base de cráneo, 10 en reconstrucción mandibular como un colgajo osteofasciocutáneo (hoy en día desplazado por el colgajo microvascularizado de peroné), ${ }^{11}$ y en defectos a nivel de paladar blando, ${ }^{4}$ siendo en la actualidad su principal indicación la reconstrucción de cavidad oral tras la resección de tumores que afectan a lengua y suelo de boca. Dentro de la reconstrucción lingual, se ha usado el colgajo radial tanto para la reconstrucción de la lengua móvil (realizando microanastómosis de la arteria lingual con la arteria radial), ${ }^{12}$ como para la reconstrucción de la base de lengua con conservación laríngea. ${ }^{13}$

Varios estudios han analizado el grado de recuperación funcional conseguido tras la reconstrucción de defectos linguales con el colgajo radial libre, fundamentalmente respecto al habla y la deglución del paciente. Además, existen estudios que pretenden evaluar la extensión y grado de recuperación espontánea de la sensibilidad tras la reconstrucción de la cavidad oral y orofarínge con colgajos libres radiales no inervados; estos estudios miden cinco modalidades sensitivas: presión, dolor, temperatura (frío y calor) y grado de discriminación de dos puntos, con el uso de colgajos radiales no inervados, ${ }^{14,15}$ o inervados, generalmente entre los nervios antebraquial cutáneo medial o lateral y el nervio lingual. $1,6,8$

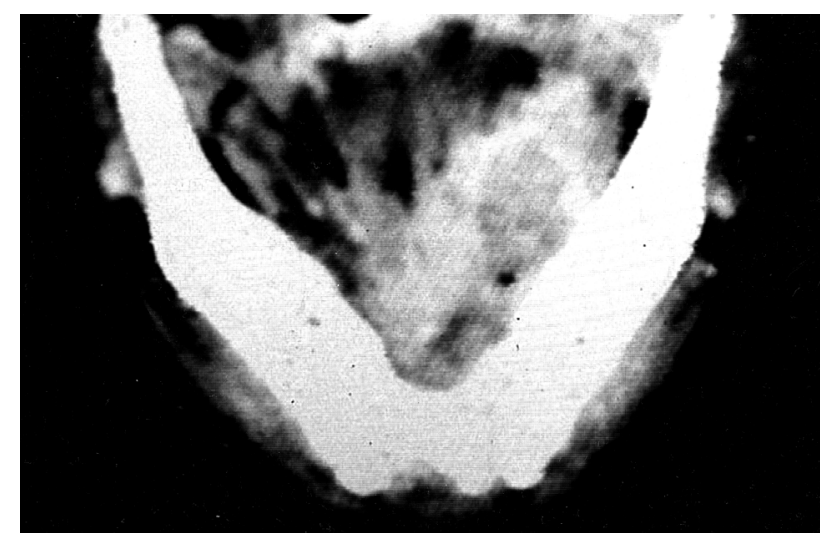

Figura 3A. Caso 2, imagen del tumor en la TC con contraste. Figure $3 A$. Case 2, image of the tumor on CT scan with contrast material.

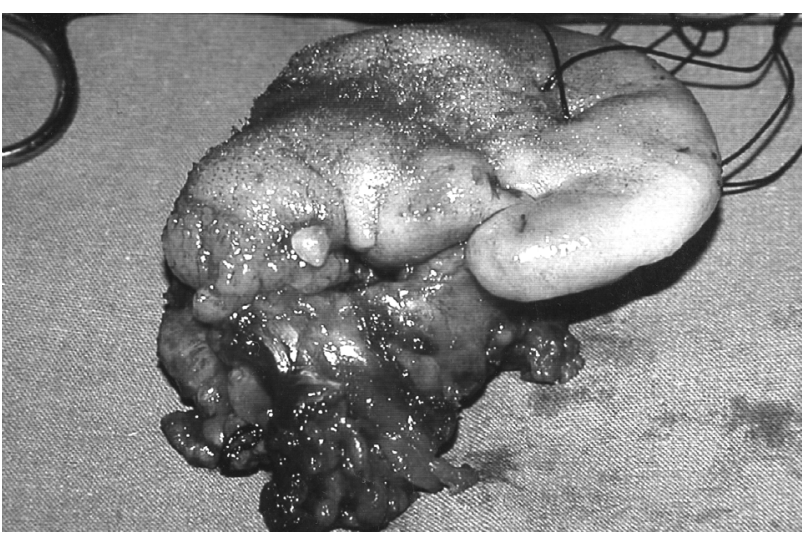

Figura 3B. Caso 2, pieza quirúrgica.

Figure 3B. Case 2, surgical specimen.

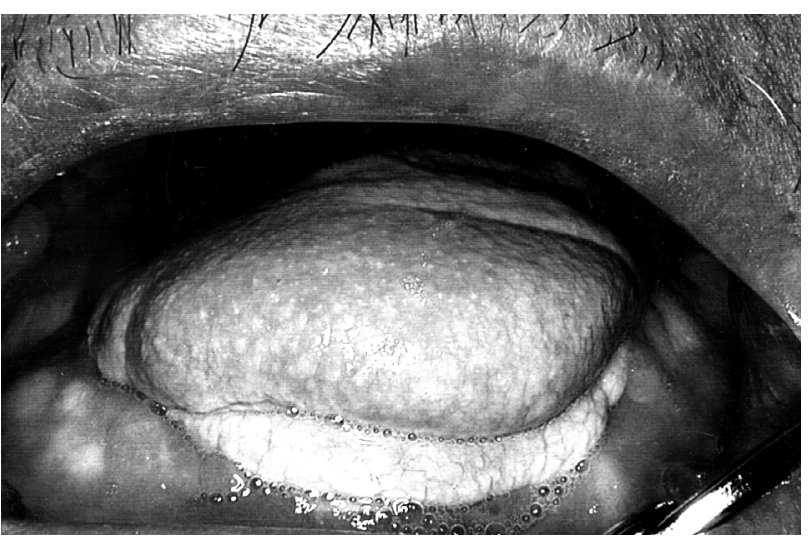

Figura 3C. Caso 2, imagen postoperatoria tras la reconstrucción. Figure 3C. Case 2, postoperative image after the reconstruction. and radiotherapy, and other factors relating to the patient (such as age, medical condition and motivation). ${ }^{5}$ Lingual function is determined by various factors: the complex activity of the different muscles that vary their shape and position, the lubrication of the mucosa and lingual surface, and sensory innervation feedback that indicates pain, temperature, touch, proprioceptive sense and taste. For improving the mobility of the reconstructed tongue, we have to take into account three surgical aspects: the introduction of a fine, pliable tissue, the use of superfluous tissue and the separation when carrying out the reconstruction of the mobile tongue and the floor of the mouth and gingiva. ${ }^{8}$ The traditional form of reconstruction after a glossectomy has been the reconstruction with myocutaneous free or pedicled flaps, and it is currently the radial forearm free flap that is ideal for maximum recovery of lingual mobility, although for reconstructing greater defects of soft parts of the oral cavity other flaps can be used such a the rectal free flap. ${ }^{6}$

In 1994 Urken and cols. designed a bilobed radial forearm flap that permitted separating the mobile tongue from the floor of the mouth and gingiva during the reconstruction. As a result postoperative mobility of the new tongue was maximized.8 Our new design with a double skin paddle increases the mobility of the reconstructed tongue, and as a result speech and swallowing function is improved together with the protection of the patient's airways, as the reconstruction of the tongue, floor of the mouth and gingiva is totally individualized because of the area that has been de-epithelialized.

The radial forearm free flap has been used for the reconstruction of cranial base defects, 10 in mandibular reconstruc- 
Jacobson y cols., evaluaron: la deglución, la movilidad lingual, la movilidad del labio mandibular y del velo del paladar, el control lingual de los labios y de la mandíbula, la masticación, la sensibilidad de la cavidad oral, la sensibilidad orofaríngea, el habla y el aspecto postoperatorio de las estructuras. Se comprobó que existía una variabilidad de los resultados funcionales obtenidos en función de la localización del tumor extirpado, y por tanto de la zona reconstruida. ${ }^{7}$ Haughey, analizó postoperatoriamente el grado de recuperación del habla y de la deglución de los pacientes, comparando dicha recuperación entre glosectomías que afectaban únicamente a la lengua móvil o a la base de la lengua. ${ }^{16}$ En nuestra opinión y en virtud de los resultados obtenidos, el colgajo radial libre de doble paleta cutánea mejora esta recuperación funcional.

Las complicaciones del sitio donante que se han descrito, incluyen: pérdida de parte del injerto cutáneo usado para cerrar la zona donante del colgajo y necrosis global del injerto cutáneo, exposición de tendones, retraso del cierre del defecto, alteraciones en la sensibilidad del antebrazo por daño en los nervios cutáneo antebraquial medial o lateral, infección del sitio donante, disminución en la sensibilidad del pulgar y la eminencia tenar, y por último neurinomas dolorosos a nivel de los cabos nerviosos. ${ }^{17-19} \mathrm{En}$ nuestra serie, no se produjo ninguna de las complicaciones antes descritas.

\section{Conclusiones}

El objetivo final en la reconstrucción de los defectos anatómicos provocados en la cirugía oncológica de tumores de la cavidad oral, es la recuperación en el mayor grado posible de las funciones del habla, deglución y protección de la vía aérea. El hecho de poder reconstruir de forma individualizada la lengua del suelo de boca y encía, va a suponer alcanzar un mayor grado de movilidad lingual, con lo cual mejoraremos la recuperación funcional del paciente y su calidad de vida tras la cirugía. Además, este colgajo, al ser sensitivo, permite tras la anastomosis nerviosa una recuperación sensitiva de la zona reconstruida. Aunque nuestra serie consta de pocos pacientes, pensamos tras los resultados obtenidos con nuestro colgajo, que se debería continuar con su uso en el futuro.

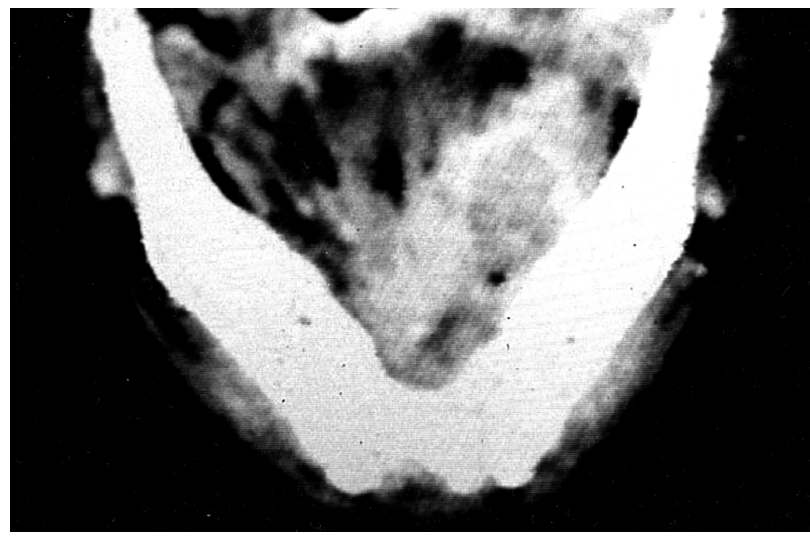

Figura 4A. Caso 3, imagen de la TC mostrando el tamaño tumoral.

Figure 4A. Case 3, image of CT scan showing tumor size.

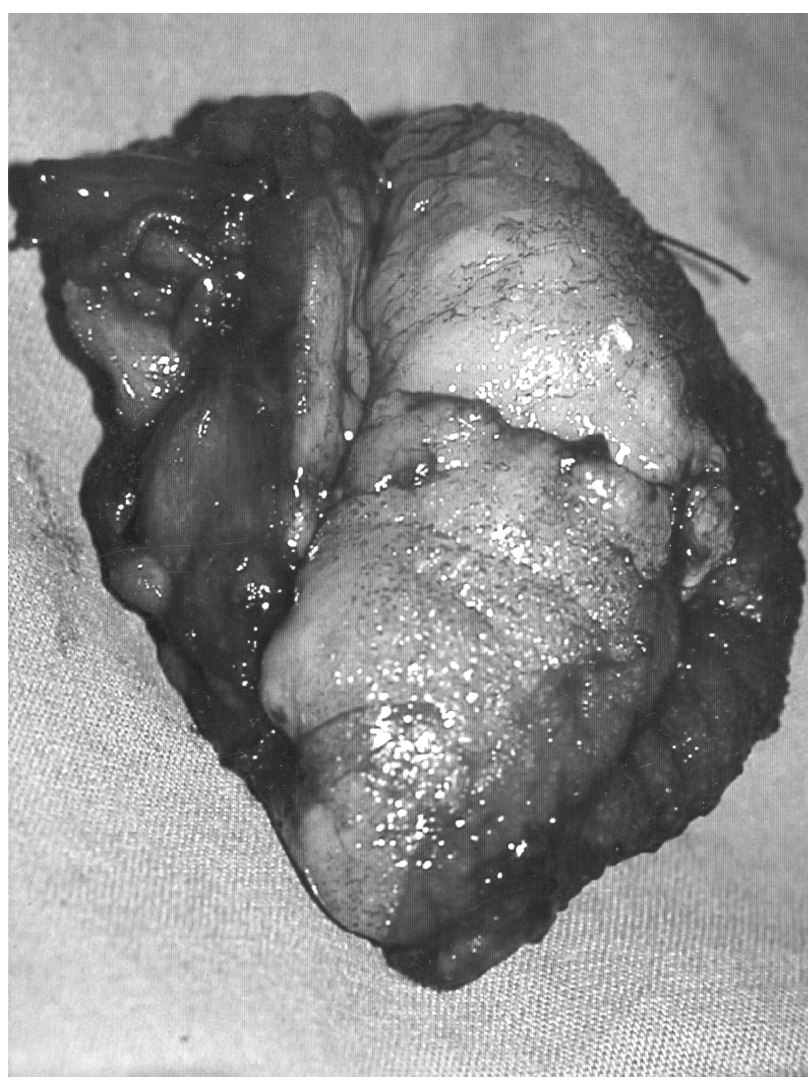

Figura 4B. Caso 3, imagen de la pieza quirúrgica.

Figure 4B. Case 3, image of surgical specimen. tion as an osteocutaneous flap (but today it has been superseded by the microvascular fibular flap, $)^{11}$ and for soft palate defects, ${ }^{4}$ with it currently being indicated chiefly for reconstructions of the oral cavity after the resection of tumors affecting the tongue and floor of the mouth. Within lingual reconstruction, the radial forearm flap has been used for the reconstruction of the mobile tongue (with microanastamosis being carried out of the lingual arteries with the radial artery), ${ }^{12}$ as well as the reconstruction of the base of the tongue with laryngeal preservation. ${ }^{13}$ Various studies have analyzed the degree of functional recovery achieved after the reconstruction of lingual defects with the radial forearm free flap, fundamentally with regard to speech and swallowing of the patient. In addition, there are studies that try to evaluate the extension and degree of spontaneous recovery of sensation after the reconstruction of the oral cavity and oropharynx with noninnervated radial forearm free flaps; these studies measure five sensory modalities: pressure, pain, temperature (cold and hot) and two point discrimination, with the use of noninnervated radial forearm flaps, ${ }^{14,15}$ or innervated, generally between the medial or lateral antebrachial cutaneous nerves and the lingual nerve. $1,6,8$

Jacobson and cols evaluated: swallowing, lingual mobility, mobility of the mandibular lip and of the soft palate, lingual control of the lips and of the mandible, mastication, oral cavity sensation, oropharyngeal sensation, speech and the postoperative appearance of structures. It was discovered that the functional outcome obtained varied according to the location of the tumor excised and, as a result, the area reconstructed.? Haughey evaluated the degree of postoperative recovery with regard to speech and swallowing of the patients, and he made 


\section{Bibliografía}

1. Kuriakose M, Loree T, Spies A. Sensate radial forearm free flaps in tongue reconstruction. Arch Otolaryngol Head Neck Surg 2001;127:1463-6.

2. Soutar DS, Scheker LR, Tanner NSB, McGregor IA. The radial forearm flap: a versatile method for intraoral reconstruction. Br J Plast Surg 1983; 36:1-8.

3. Eckardt A, Fokas K. Microsurgical reconstruction in the head and neck region: 18-year experience with 500 consecutive cases. I Craniomaxillofac Surg 2003;31:197-201.

4. Lacombe V, Blackwell K. Radial forearm free flap for soft palate reconstructions. Arch Fac Plast Surg 1999;1:130-2.

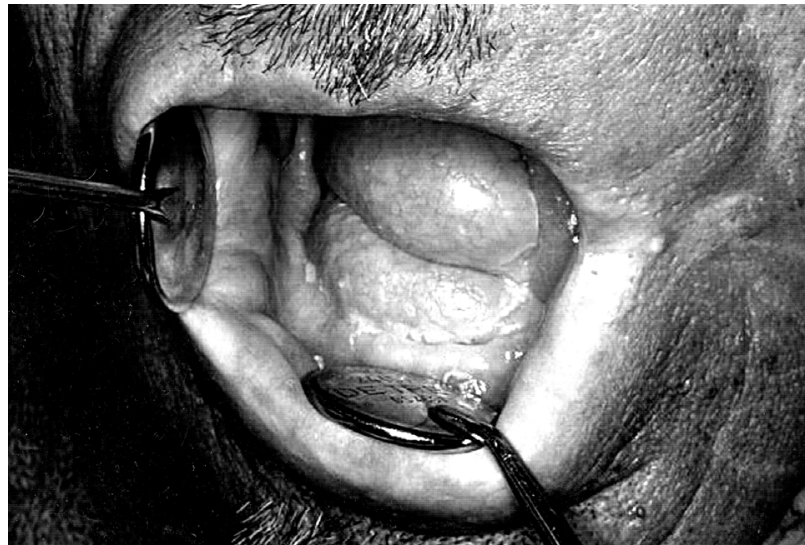

Figura 4C. Caso 3, cavidad oral reconstruida tras la resección tumoral.

Figure 4C. Case 3, reconstructed oral cavity after tumor resection. a comparison between glossectomies that affected just the mobile tongue and those affecting the base of the tongue. ${ }^{16}$ In our opinion, and in view of the results obtained, the radial forearm free flap with a double skin paddle improves functional recovery.

Complications in the donor site that have been described include: loss of part of the skin graft used for closing the donor site of the flap and global necrosis of the skin graft, exposure of tendons, delay in the closure of the defect, sensation changes of the forearm because of damage to the medial or lateral antebrachial cutaneous nerves, infection of the donor site, reduction of sensation of the thumb and thenar eminence, and lastly painful neurinomas by the nerve cables. ${ }^{17-19}$ In our series, none of these complications arose.

\section{Conclusion}

The final objective when reconstructing the anatomic defects produced by oncological surgery of tumors of the oral cavity, is the recovery as far as possible of speech and swallowing functions, and the protection of the airways. The fact that the tongue, floor of the mouth and gingiva can be reconstructed in an individualized fashion, means that a greater degree of lingual mobility is achieved, which means that the functional recovery of the patient and postoperative quality of life is improved. In addition to this, as this flap has sensitivity, after the anastomosis of the nerves, the reconstructed area will recover sensation. Although our series has very few patients we believe that, given the results obtained with our flap, it should continue to be used in the future.

14. Chambers P. A, Harris L., Mitchell D. A, Corrigan A. M. Comparative study of the ipsilateral full thickness forearm skin graft in closure of radial forearm flap donor site defects. J Cranio-maxillofac Surg 1997;25:245-8.

15. Lvoff G, O`Brien C, Cope C, Lee K. Sensory recorvery in noninnervated radial forearm free flap in oral and oropharyngeal reconstruction. Arch Otolaryngol Head Neck Surg 1998;124:1206-8.

16. Haughey B, Taylor M, Fuller D. Fasciocutaneous flap reconstruction of the tongue and floor of mouth. Arch Otolaryngol Head Neck Surg 2002;128:138895.

17. Urken M, Futran N, Moscoso J, Biller H. A modified design of the buried radial forearm free flap for use in oral cavity and pharyngeal reconstructions. Arch Otolaryngol Head Neck Surg 1994;120:1233-9.

18. Timmons MJ. The vascular basis of the radial forearm flap. Plast Reconstr Surg 1986;77:80-91.

19. Futran ND, Gal TJ, Farwell G. Radial forearm free flap. Oral Maxillofac Surg Clin Nort Am 2003;15:577-91. 